DOI https://doi.org/10.18551/rjoas.2018-08.23

\title{
FACTORS INFLUENCING VOLUNTARY AUDITOR SWITCHING AND AUDIT FEE AS A MODERATING VARIABLE: AN INDONESIAN CASE STUDY
}

\author{
Maharani Yunita, Wahyudi Tertiarto, Azwardi \\ University of Sriwijaya, Indonesia \\ *E-mail: yunita7691@yahoo.co.id
}

\begin{abstract}
The purpose of this study was to determine the factors that voluntary auditor switching on property and real estate companies with the audit fee as moderation. The data used in this study was obtained from BEl is as property and real estate company that publishes the complete audited financial statements (in rupiah) listed on the Stock Exchange from 20092014. The samples were 180 observations determined by purposive sampling technique. The data analysis technique was is logistic regression and interaction test. Based on the analysis conducted, the results showed that the percentage change audit opinion, change of management did not affect had companies to perform auditor switching, while financial distress and audit fee had significant influence on the company perform the auditor switching. Audit fee enhanced the effect financial distress of auditor switching.
\end{abstract}

\section{KEY WORDS}

Audit opinion, financial distress, management, voluntary auditor, audit fee.

Companies registered on the stock exchange have responsibility on issuing financial statements audited by an independent auditor. According to (Astrini et al., 2013) that financial statements will be used as reference to determine the position and financial activities of a company. Related to the number of parties having an interest in the report cause the financial statements must be audited to ensure its fairness so it is not mislead the parties who use it so that the needs of each user report can be met. So the independency of auditor is the main key of the auditor profession. According to (Wijayani, 2011) that independency must be absolute to the auditor's belonging when the auditors perform auditing duties requiring the auditor to attest to the fairness of their client's financial statements. The independency attitude means that an auditor is not easily influenced, so the auditor will report what he or she discovered during the auditing process (SPAP, 2013). The conflict occurs because the possibility of the agent does not always act in accordance with the interests of the principal and trigger agency costs. In agency theory, the independent auditor acts as an intermediary between different interest between agent and principle. Independent auditors also serve to reduce agency costs arising from self-serving behavior by agents (managers). Thus, to prevent the loss of auditor independency, the government regulates auditor switching obligations. One of the government basis in regulate the auditor switching obligation is because of the case of Arthur Anderson's Public Accountant Firm with his client Enron.

The obligation regarding to auditor changing has been regulated by the government Regulation of the Minister of Finance of the Republic of Indonesia No. 17 / PMK.01 / 2008. Switching of Public Accountant voluntary was conducted by many companies in Indonesia. This is evidenced by the existence of data showing that 30 companies of property and real estate registered on the stock exchange of Indonesia during the year 2009-2014. From the 30 companies, voluntary switching auditors recorded a total of 12 companies. According to Nasser et. Al (2006) frequent change of Public Accountant will result in increasing audit fees. When the auditor first audits a single client, the auditor should understand the client's business environment and the client's audit risk. For auditors who are totally unaware of the two issues, the start up costs are high so raising the audit fee.

According to (Sinarwati, 2010), if there is any change of auditor by the company outside the stipulated rules, it will cause suspicion from third party, so it is important to know the cause factors. This research intends to re-confirm the factors affecting the occurrence of 
voluntary auditors switching in property and real estate companies. The different opinion about what factors cause the voluntary auditor switching at property and real estate companies in Indonesia is interesting to be a research topic considering the existence of parties that support and does not support with the implementation of voluntary auditor switching.

\section{LITERATURE REVIEW}

Agency Theory. Agency Theory is an underlying theory base on auditors switching. According to (Jensen, 1976) raiing the agency costs in order to overcome the agency conflict. Agency costs occur to protect the interests of the owner and to reduce the likelihood that the agent conducts mislead behaviour. Due to a conflict of interest between both parties (the principal and the agent), it is necessary to have an independent party that is an independent auditor. The independent auditor acts as a mediator between both parties (the principal and the agent). In Indonesia, auditor changing consists of two types, namely mandatory and voluntary. Auditor switching can be conducted from corporate will such as giving an audit opinion that does not meet management expectations, financial distress, CEO changing Public Accountantcapasity, auditor reputation from the auditor's side such as audit fee. In this research, property and real estate companies in Indonesia are still frequently doing by voluntarily auditor. This is what needs to be investigated because as we know that too many auditors change, making investors suspicious and can lower stock prices on the stock exchange as well as the company's image getting worse.

Audit Opinion. Audit opinion is a statement or opinion given by the auditor, and statements or opinions are given for the company to know about the fairness of its financial statements (Putra, 2014). Audit opinion may trigger the client to change its auditor when the client does not agree with the audit opinion of the previous year provided by the auditor (Fitriani et al., 2014)

Financial Distress. According to (Astrini et al, 2013) financial distress is an uncertainty in the business of companies that are experiencing financial difficulties and even threatened to bankrupt raises the conditions encouraging companies to choose th Public Accountant.

Management Changing. Based on agency theory, management as an agent is assumed to have a personal interest and this maximizes its importance. With its authority, management has the authority to decide to replace the auditor (Yuka et al. 2016). The management changing occurred is caused by the decision of the general meeting of shareholders to evaluate the performance of the previous management is considered bad and not achieved the target according to the commissioner's ideal expectasy.

Audit fee. According to (Agoes, 2012) defines audit fee that is the amount of the cost depends on among others is the assignment risk, the services complexity provided, the expertise level required to perform the service, the cost structure of Public Accountant and other professional considerations.

This research has seven hypothesisas follow:

- H1: Audit opinion affects the auditor switching;

- H2: Financial Distress affects the auditor switching;

- H3: Management changing affects the auditor switching;

- H4: Audit fee affects the auditor switching;

- H5: Audit fee affects the relationship between audit opinion and the auditor switching;

- H6: Audit fee affects the relationship between management changing and auditor switching;

- H7: Audit fees affect the relationship between financial distress and the auditor switching.

\section{METHODS OF RESEARCH}

Data collection methods in this research used literature study through books, journals, and using secondary data by accessing the financial statements of property and real estate 
companies registered on the Indonesia Stock Exchange 2009-2014. The populations in this study were 48 property and real estate companies registeredon Indonesia Stock Exchange (IDX) period 2009-2014. But in this research the researcher will use purposive sampling method because of 48 property companies and real estate that has established in Indonesia, 30 companies that have data for 6 consecutive years from 2009-2014 and according to criteria.

Auditor Switching. When the company conducts a changing of Public Accounting Firm (Auditor Switching) voluntarily then assigned a value of 1 . Meanwhile, if the company does not change the Auditor Switching thenassigned value of 0 (Chadegani et al., 2011).

Audit Opinion. Companies that receive fair opinions are assigned value of 1 (one) while zero (0) represents companies that get opinions other than unqualified (Wijayani, 2010).

Financial Distress. The term financial distress is used to reflect problems with liquidity that can not be answered or resolved without having to change the scale of operations or corporate restructuring (Munawir, 2012). These variable measurements previously referred to the research Taufiq et.al (2016), where the measurement of variables with ratios and calculations using the modified Altman formula is:

$$
Z^{\prime \prime}=6,56 \times 1+3,26 \times 2+6,72 \times 3+1,05 X 4
$$

Management Changing. This variable measurement has previously been used by (Chadegani et al., 2011). Management changing variables are measured using dummy variables. If there is a director changing / CEO in the company then assigned the value of 1 . But when there is no director changing in the company, then assigned the value of 0 .

Audit Fee. The audit fee variable will be represented by the professional fees account contained in the financial statements of property and real estate registered in Stock exchange in 2009-2014. Measurements of these variables have previously been used by (Listya et al., 2014). In this research, audit fee symbolized by $L_{n}$ fee. Natural logarithms are used to minimize the difference in numbers that are too far from the sample data obtained.

Model Specification. The analysis used in this research is logistic regression analysis:

$$
\text { SWITCH }=\alpha+\beta_{1} O A+\beta_{2} F D+\beta_{3} P M+e
$$

Where: SWITCH = Dummy auditor switching variable (category 1 (one) to perform; auditorswitching and 0 (zero) not to perform auditor switching; $\alpha=$ constants; $\beta 1-\beta 3=$ regression coefficient; $\mathrm{OA}=$ Audit Opinion; FD = Financial Distress; $\mathrm{MC}=$ Management Changing; $\mathrm{e}=$ Error.

Moderated Regression Analysis (MRA). In this research, the measurement instrument of moderation variable using Moderated Regression Analysis (MRA). According Wibowo (2009) Moderated Regression Analysis (MRA) is a special application of multiple linear regression containing elements of interaction (multiplication of two or independent). With the equations developed as follows.

$$
\begin{gathered}
\text { Model 1: } \operatorname{Ln} \frac{\mathrm{p}}{1-p}=\alpha+\beta 1_{\mathrm{OA}}+\beta 2_{\mathrm{FD}}+\beta 3_{\mathrm{PM}} \\
\text { Model 2: } \operatorname{Ln} \frac{\mathrm{p}}{1-p}=\alpha+\beta_{1 \mathrm{OA}}+\beta_{2 \mathrm{FD}}+\beta_{3 \mathrm{PM}+}+\beta_{4 \mathrm{AF}} \\
\text { Model 3: } \operatorname{Ln} \frac{\mathrm{p}}{1-p}=\alpha+\beta_{1 \mathrm{OA}}+\beta_{2 \mathrm{FD}}+\beta_{3 \mathrm{PM}}+\beta_{4 \mathrm{AF}+} \beta_{5(\mathrm{OA} \times \mathrm{AF})}+\beta_{6(\mathrm{FD} \times \mathrm{AF})}+\beta_{7(\mathrm{PM} \times \mathrm{AF})}
\end{gathered}
$$

Methods in this study consists of 1) Descriptive statistics, 2) Hypothesis testing is conducted by using $a=5 \%$. The rules of decision making are: If the probability value (sig.) < $a=5 \%$ then the hypothesis is accepted. If the probability value (sig.) $>a=5 \%$ then the hypothesis is rejected (Wijayani, 2011).

The stages of hypothesis testing in logistic regression are as follows:

Assessing Overall Model. Some statistical tests are given to assess this. The hypothesis for assessing the fit model are:

- $\mathrm{H}_{0}$ : The hypothesized model fit with the data; 
- $\mathrm{H}_{\mathrm{A}}$ : The hypothesized model is not fit with the data.

To test the null and alternative hypothesis, $\mathrm{L}$ is transformed into $2 \mathrm{Log} \mathrm{L}$ : Likelihood decrease $(-2 \mathrm{LogL})$ shows a better regression model or in other words a hypothesized model fit with data (Ghozali, 2013: 340).

Coefficient of Determination (Nagelkerke $R$ Square). Cox and Snell's R Square are measurment that attempt to imitate the size of R2 in multiple regression based on the likelihood estimation technique with a maximum value of less than 1 (one) so that it is difficult to interpret. Nagelkerke's $R$ square is a modification of Cox and Snell coefficients to ensure that its value varies from 0 (zero) to 1 (one) (Ghozali, 2013: 341).

Regression Model Eligibility Test. When the statistical value of Hosmer and Lemeshow's Goodness of Fit Test is to test the eligibility of the regression model is higher than 0.05 , so the null hypothesis can not be rejected and it means the model is able to predict the observed value or it can be said that the model is acceptable because it matches the observation data (Ghozali, 2013: 341).

Multicollinearity Test. A good regression model should not be correlated between independent variables. If independent variables are correlated, these variables are not orthogonal. Orthogonal variables are independent variables that are mutually correlated among the same variables with zero (Ghozali, 2013: 105).

Classification Matrix. The classification matrix shows the predictive power of the regression model to predict the possibility of Public Accountant firmswitching by a company (Wijayani, 2011).

Logistic Regression. The analysis used in this research is logistic regression analysis, that is by looking at the influence of audit opinion, financial distress, switching management to voluntary auditor switching on the company of property sector and real estate. The regression model in this study as follows:

$$
\text { SWITCH }=\alpha+\beta_{1} \mathrm{OA}+\beta_{2} \mathrm{FD}+\beta_{3} \mathrm{PM}+e
$$

\section{RESULTS AND DISCUSSION}

Descriptive statistics are used to provide an overview or description of the data under the research by looking at mean, standard deviation, and maximum-minimum of values.

Table 1 - Descriptive statistics

\begin{tabular}{llllll}
\hline & $\mathrm{N}$ & Minimum & Maximum & Mean & Std. Deviation \\
\hline OA & 180 &, 00 & 1,00 &, 4444 &, 49829 \\
FD & 180 &, 01 & 3,80 &, 8321 &, 58274 \\
PM & 180 &, 00 & 1,00 &, 6521 &, 47272 \\
AF & 180 & 18,14 & 25,43 & 21,6927 & 1,60955 \\
AS & 180 &, 00 & 1,00 &, 2444 &, 43096 \\
Valid N (listwise) & 180 & & & & \\
\hline
\end{tabular}

Source: Data Processing Results.

Logistic Regression Test Results. According to (Ghozali, 2013) that logistic regression can be used to analyze data with dummy variables as the dependent variable.

Table 2 - Variables in the Equation

\begin{tabular}{lll}
\hline Variable & B & Sign \\
\hline Opini Audit &, 149 & 0,687 \\
Financial Distress &, 038 & 0.002 \\
Pergantian Manajemen & 1,580 & 0.531 \\
\hline Constant & $-2,036$ & \\
\hline
\end{tabular}

Source: Data Processing Results

$$
\text { Switch }=-2,036+0,1490 A+0,038 F D+1.580 P M
$$


Audit opinion variable has a significance of 0.687 which means higher than 0.05 . It shows that the first hypothesis $(\mathrm{H} 1)$ is unsuccessful (rejected). Financial distress variable has the value of regression coefficient 0.038 , financial distress significance value 0.002 which means smaller than the significance of 0.05 . It shows that the second hypothesis $(\mathrm{H} 2)$ is successfully supported (accepted). Variable of management changing has coefficient equal to 1,580 with value of significance 0,531 which meanshigher than significance value 0,05 . It shows that the third hypothesis $(\mathrm{H} 3)$ is rejected. Thus, the management changing has no effect on the voluntary auditor witching to the company.

Table 3 - Variables in the Equation

\begin{tabular}{lll}
\hline Variable & B & Sign \\
\hline Opini Audit &, 052 &, 891 \\
Financial Distress &, 019 &, 766 \\
Pergantian Manajemen & 1,540 &, 000 \\
\hline Audit Fee &,- 223 &, 034 \\
\hline Constant & 2,907 &, 283 \\
\hline
\end{tabular}

Source: Data Processing Results.

$$
\text { Switch }=2,907+0,052 \mathrm{OA}+0,019 \mathrm{FD}+1,540 \mathrm{PM}-0,223 \mathrm{AF}
$$

From the processed data, the equation of the regression model formed in equation two that the audit opinion variable has a significance value of $0.891>\alpha=5 \%$ with the regression coefficient value of 0.005 which means the audit opinion variable in equation two is not significant. financial distresss significance value is $0.766>\alpha=5 \%$ with a positive regression coefficient value of 0.019 which means the variable financial distresss in equation two does not give effect to the voluntary auditor switching. In addition, the management changing variables has a value of 0.000 with regression coefficient value of 1,540 which means the management changing variable in equation two has an effect to the voluntary auditor switching. It shows that the hypothesis is accepted. So it can be concluded that the management changing has a positive and significant influence on the voluntary auditor switching.

The next discussion on the variable audit fee that it has a value of $0.034<\alpha=5 \%$ with the regression coefficient value of -0.223 which means that the audit fee variable in equation two has a negative influence on the voluntary auditor switching. It shows that the fourth hypothesis $(\mathrm{H} 4)$ is accepted.

Table 4 - Variables in the Equation

\begin{tabular}{lll}
\hline & $\mathrm{B}$ & Sig. \\
\hline Opini Audit & 3,162 &, 732 \\
Financial Distress & $-1,779$ &, 296 \\
Pergantian Manajemen & $-21,717$ &, 997 \\
Audit Fee &, 173 &, 703 \\
INTERAKSI_1 &,- 197 &, 652 \\
INTERAKSI_2 &, 074 &, 014 \\
INTERAKSI_3 & 45,397 &, 996 \\
\hline Constant & $-6,102$ &, 535 \\
\hline
\end{tabular}

Source: Data Processing Results.

$$
\begin{gathered}
\text { Switch }=-6,102+3,162 \mathrm{OA}-1,779 \mathrm{FD}-21,717 \mathrm{PM}+0,173 \mathrm{AF}-0,1970 \mathrm{AxAF}+0,074 \mathrm{FDxAF}+ \\
\text { 45,397 PMxAF }
\end{gathered}
$$

From the processed data, the regression model equation formed at equation three, Interaction variable 1 has value equal to $0,652>\alpha=5 \%$ with negative regression coefficient value of $-0,197$ from result of interaction calculation between audit opinion variable with audit fee has negative direction hence hypothesis five (H5) shows that audit fee variable weakening influence of audit opinion on the auditor switching and not significant. 
Then, the interaction variable 2 has a value of $0.014<\alpha=5 \%$ with a positive regression coefficient value of 0,074 from the calculation of interaction between financial distress variables with audit fee gives direction of positive relationship then the sixth hypothesis $(\mathrm{H} 6)$ mentions audit fee variables strengthen the influence of financial distress on auditors switching is accepted.

After that, the interaction variable 3 has a significance value of $0.996>\alpha=5 \%$ with a positive regression coefficient value of 45,397 from the interaction calculation between the management changing variable and the audit fee giving the positive relationship then the hypothesis reinforces the effect of management changing on the auditor switching but not significant the seventh hypothesis $(\mathrm{H} 7)$ is rejected.

The results of this research illustrate that voluntary auditor switching in property and real estate companies are due to financial distress and audit fees. It is reflected in the condition of the Indonesian economy that has grown below 7 (seven) percent in the last 5 years, resulting in lower public purchasing power on housing investment. This factor also causes the company's capital cash flows to be in hampered. This research is in accordance with (Dwiyanti et al., 2014); (Widyanti et al., 2016) shows that financial distress affects the voluntary auditor switching. According to (Nasser et al., 2006) the business uncertainty in companies facing financial difficulties can lead to a condition that encourages companies to swith their Public Accountants. Becoming threats to financial difficulties and also costs that companies will face.

Because there are conflicts of interest in which management is more likely to spend more time committed to avoiding bankruptcy and trying to reveal its performance than to make decisions to make better management of the company. So the companies that are lead to threat with bankruptcy and face unhealthy financial position will usually use the services of high independent auditors to increase shareholder and creditor confidence and also to reduce the risk of litigation.

\section{CONCLUSION}

Based on the results of hypothesis testing in the logistic regression analysis, it was found that the percentage of audit opinion variable, the management changing did not affect the voluntary switching auditor, while the financial distress variable, audit fee statistically affect the voluntary auditor switching. And the moderate variable audit fee strengthens the effect of financial distress on voluntary auditors switching.

\section{REFERENCES}

1. Agoes, Sukrisno. (2012). Auditing Petunjuk Praktis Pemeriksaan Akuntan Oleh Akuntan Publik.Salemba Empat. Jakarta

2. Astrini, Novia Retno dan Muid, Dul. (2013). Analisis Faktor-Faktor yang Mempengaruhi Perusahaan Melakukan Auditor Switching Secara Voluntary. Diponegoro Journal of Accounting Volume 2, Nomor 3, Tahun 2013, Halaman 1-11ISSN (Online): 2337-3806.

3. Chadegani, A. A., Mohamed, Z. M., \& Jari, A. (2011). The Determinant Factors of Auditor Switch among Companies Listed on Tehran Stock Exchange. International Research Journal of Finance and Economics, 80(80), 158-168.

4. Dwiyanti, R Meike Erika dan Sabeni, Arifin. (2014). Faktor-Faktor yang Mempengaruhi Auditor Switching Secara Voluntary. Diponegoro Journal of Accounting Volume 3, Nomor 3, Tahun 2014, Halaman 1 ISSN (Online): 2337-3806.

5. Faradila, Yuka., Rizal Yahya M. (2016) Pengaruh Opini Audit, Financial Distress, Dan Pertumbuhan Terhadap Auditor Switching. Jurnal Ilmiah Mahasiswa Ekonomi Akuntansi, Vol. 1, No. 1 Halaman 81-100.

6. Fitriani, N. A., \& Zulaikha. (2014). Analisis Faktor- Faktor yang Mempengaruhi Voluntary Auditor Switching di Perusahaan Manufaktur Indonesia. Diponegoro Journal of Accounting 3(2). 
7. Ghozali, Imam. (2013). Aplikasi Analisis Multivariate dengan Program IBM 21 SPSS. Semarang: Badan Penerbit Universitas Diponegoro

8. Institut Akuntan Publik Indonesia. (2013). Standar Profesional Akuntan Publik "Standar Audit (SA) 570". Jakarta Selatan: Salemba Empat.

9. Jensen, M.C and Meckling, W. H. (1976). Theory Of The Firm, Managerial Behaviour, Agency Costs \& Ownership Structure. Journal of Financial Economics.

10. Listya Yuniastuti Rahmina, Sukrisno Agoes, (2014). Influence of auditor independence, audit tenure, and audit fee on audit quality of members of capital market accountant forum in Indonesia. Journal Procedia - Social and Behavioral Sciences. 16(4): h: 324-331

11. Menteri Keuangan, 2008, Peraturan Menteri Keuangan Republik Indonesia Nomor 17/PMK.01/2008 tentang “Jasa Akuntan Publik", Jakarta.

12. Munawir, S. (2012). Analisa Laporan Keuangan. Cetakan Kelima. Penerbit PT. Raja Grafindo Persada. Jakarta.

13. Nasser, A.T.A., Wahid, E.A., Nazri, N.S.F.S.M., Hudaib, M. (2006). Auditor Client Relationship: The Case of Audit Tenure and Auditor Switching in Malaysia. Managerial Auditing Journal, 21 (7), pp: 724-737.

14. Putra, I W. D. W. (2014). Pengaruh Financial Distress, Rentabilitas, Pertumbuhan Perusahaan dan Opini Audit Pada Pergantian Auditor. EJurnal Akuntansi Universitas Udayana. HIm. 308-323.

15. Sinarwati, Ni Kadek. (2010). Mengapa Perusahaan Manufaktur yang Terdaftar di BEI Melakukan Pergantian Kantor Akuntan Publik?.SimposiumNasional Akuntansi XIII Purwokerto.

16. Taufiq, Abadi M., Ghoniyah, Nunung. (2016). Studi Potensi Kebangkrutan Pada Perusahaan Industri Properti Yang Go PublicDi Bursa Efek Indonesia. Jurnal Riset Bisnis Indonesia, Vol. 13, No. 1, Halaman 91-100

17. Wibowo, Arie dan Rossieta, Hilda. (2009). Faktor-Faktor Determinasi Kualitas AuditSuatu Studi dengan Pendekatan Earning Surprise Benchmark. Simposium Nasional Akuntansi XII, Palembang, hal. 1-34

18. Widyanti, A.A. S Istri, A., \& Badera, I. D. N. (2016). Reputasi Auditor Sebagai Pemoderasi Pengaruh Financial Distress Pada Auditor Switching. Jurnal Akuntansi Universitas Udayana, 16.3, 1800-1828.

19. Wijayani, E.D. dan Januarti, Indira. (2011). "Analisis Faktor - faktor yang mempengaruhi perusahaan di Indonesia melakukan Auditor Switching". SNA XIV 2011. Aceh. 